\title{
Cerebellar Abiotrophy in a Moose (Alces alces L) Related to Copper Deficiency. A Case report
}

During december 1992 a moose cow with severely incoordinated and atactic movements was observed at several occasions in an area $20 \mathrm{~km}$ north of Uppsala. She was followed by a calf with normal movements and appearance. The 31 of January the cow was found laying in the forest unable to raise and walk. She was killed by means of a rifle shot in the neck and necropsied on the spot.

Necropsy revealed no macroscopically visible changes but a moderate dehydration. The cow was pregnant with a normally developed calf. The spinal canal was not opened and thus the spinal cord was neither inspected nor sampled as this was impossible to perform in the forest. Samples from visceral and endocrine organs and brain were fixed in $10 \%$ buffered formaldehyde and in addition material from liver and kidney was collected and deep frozen for the purpose of chemical analysis. The jaws were collected for age determination.

The cow was found to be $5 \frac{1}{2}$ year old. The relative weight of the cerebellum in relation to the cerebrum was calculated according to Björk et al. (1973) on formalin fixed tissues and found to be $10 \%$.

For a comparison the weight of the formalin fixed cerebellum and cerebrum of 2 cows and 2 yearlings was recorded. The weight of the cerebellum varied from 11.2 to 12.2 per cent of the weight of the cerebrum. (The calves were shot during regular hunting, the cows were submitted for necropsy; 1 died from trauma hit by a car and 1 from starvation due

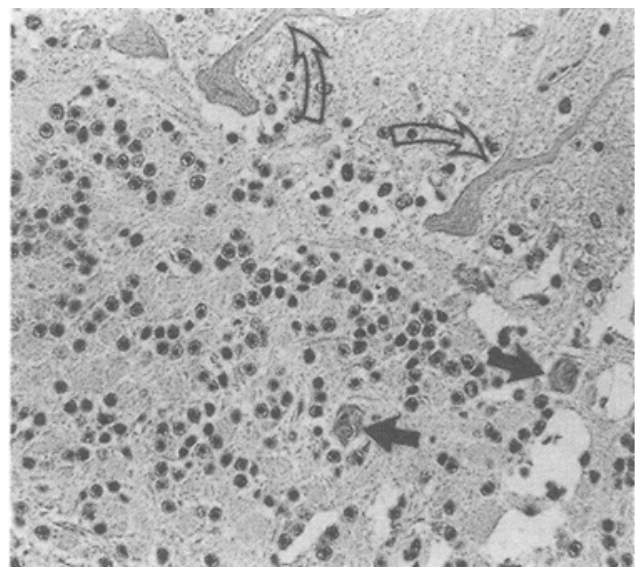

F1gure 1. Cerebellum from moose cow with cerebellar abiotrophy. Note swollen Purkinje cells with markedly swollen dendrites (open arrows), decreased cellularity of and ectopic Purkinje cells in the granular layer (filled arrows). HEx75

to old age.) Samples for histology were paraffin embedded, cut $5 \mu \mathrm{m}$ and stained with hematoxylin and eosin, periodic acid Schiff, Luxol fast blue myelin stain and according to Cajal for astrocytes.

The histological investigation revealed as the only finding, a patchy cerebellar hypoplasia, an abiotrophy, of the cerebellum characterized by a marked thinning and decreased cellularity of the granular layer and, a severe loss of Purkinje cells leaving empty "baskets" as reminiscences. The remaining Purkinje cells were swollen with markedly swollen dendrites, in addition some few of them were 
shrunken. In the granular layer some Purkinje cells were present considered to be ectopic (Fig.1).

The lower weight ratio, cerebellum/cerebrum, in the diseased cow compared with the animals without a history of central nervous disturbances and with no microscopical lesions indicates a cerebellar hypoplasia.

Chemical analysis was carried out on liver and kidney material regarding metals $(\mathrm{Al}, \mathrm{Ca}, \mathrm{Cd}$, $\mathrm{Co}, \mathrm{Cr}, \mathrm{Cu}, \mathrm{Fe}, \mathrm{Mg}, \mathrm{Mn}, \mathrm{Ni}, \mathrm{Pb}, \mathrm{V}, \mathrm{W}, \mathrm{Zn}$ ), sulphur, selenium, retinol and alfa-tocopherol. In addition the content of the same metals and sulphur was investigated in the main fodder resources (pine and birch twigs) and water available in the area. The chemical investigations revealed very low copper values in the liver and kidney (3.9 resp. $2.2 \mathrm{mg} / \mathrm{kg}$ wet weight). All other values were within normal ranges when compared with a material of 116 clinically healthy moose sampled in Uppsala county 1982 (Frank \& Petersson, unpublished observations). In addition the copper content of the fodder was low (pine and birch twigs 4.2 resp $4.4 \mathrm{mg} / \mathrm{kg}$ wet weight $4.3 \mathrm{resp} 5.7 \mathrm{mg} / \mathrm{kg}$ dry matter) as was the case concerning drinking water obtained from 3 different sources, a creek, a ditch and a swamp, the values varying between 0.003 and $0.009 \mathrm{mg} / \mathrm{l}$. The threshold values used to differentiate deficient from normal animals concerning copper is suggested to be $5 \mathrm{mg}$ copper per kg liver dry matter (Smith \& Coup 1973) while Frank (1992) and Wikse et al. (1992) associate deficiency with values below $10 \mathrm{mg} / \mathrm{kg}$ wet weight. Adult cattle cows need an oral supplement of 150$450 \mathrm{mg}$ copper per day equivalent to $10-30$ $\mathrm{mg} / \mathrm{kg}$ dry matter of fodder (Rogers 1991) while Wikse et al. (1992) state $8-10 \mathrm{mg} / \mathrm{kg}$ dry matter of fodder. However, detrimental effects on the digestion, resorption and metabolism of copper excerted by other minerals such as molybdenum, sulphur and iron and also fodder rich in protein may increase many folds the requirement for copper (Suttle 1992, Wikse et al. 1992). High intakes of cadmium may also considerably decrease copper storage (Gawthorne 1987). High contents of fiber, which is normal in the fodder of moose, also limits copper absorption (Suttle 1983). Wikse et al. (1992) report on forages suspected to be associated with copper deficiency containing 5.4 and 4.3 ppm copper and not affected by high values of molybdenum and sulphur.

Very low copper value in the liver and in kidney and also the low copper values of the fodder and water available indicates that the moose cow suffered from primary copper deficiency.

The term abiotrophy was coined to describe the selective premature decay of a functionally related population of neurons (Calne et al. 1986). Cerebellar abiotrophy is found in a number of species of animals and it is mostly stated to be of genetic background (Lahunta 1990). Cerebellar lesions have been reported infrequently in swayback lambs (Suttle \& Field 1969, Cordy \& Knight 1978, Harper et al. 1986), but developmental abnormalities of the cerebellum and degenerative changes in Purkinje cells occur only occasionally.

By contrast a high proportion of goats with swayback have well defined lesions in the cerebellum. The characteristic lesions being hypoplasia of the granular layer and degeneration and necrosis of Purkinje cells (Fell 1987). Costa et al. (personal communication 1993) has shown that cerebellar abiotrophy occurs in copper deficient goats in Mozambique. Enzootic ataxia of deer resembles ovine enzootic ataxia presenting bilateral symmetrical demyelination at all levels of the spinal cord. Both diseases associated with low copper values (Barlow \& Butler 1964). An important difference is that enzootic ataxia in sheep occurs in the new born and young whereas clinical 
signs are seen only in deer aged 9 months and older (Wilson et al. 1979). In the moose cow it was not possible, due to the circumstances, to investigate the spinal cord and in the material obtained no signs of demyelination was found. The histological findings in the moose cow differed markedly from the findings reported from cases of chronic wasting disease in deer (Wiliams \& Young 1993) which belongs to the spongiform encephalopaties.

The clinical picture and the histological and chemical findings in the moose cow indicates a cerebellar abiotrophy produced by a primary copper deficiency.

In a substantial part of the animals found dead or suffering from the so called Älvsborgs disease of moose in southern Sweden, the copper values are of the same magnitude or even much lower than in this cow. In addition Flynn et al. (1977) report on indications of copper deficiency in a clinically healthy subpopulation of Alaskan moose. Copper deficiency is perhaps an overlooked problem in moose and could possibly explain some of the clinical conditions reported. In domestic ruminants conditions caused by copper deficiency are e.g.: coat changes, unthriftiness, diarrhoea, lameness, bone fractures due to osteoporosis, anemia, sudden death (rupture of large vessels or myocardial atrophy in adults (falling disease), all of them found in moose. In addition conditions of multifactorial genesis such as infectious diseases due to impaired immune response, abomasal ulcers, polio encephalomalacia, subclinical syndromes as low growth rates and low fertility rates may be associated with copper defiency (Wikse et al. 1992).

\section{Acknowledgement}

We thank Lennart Eriksson for locatıng the anımal and valuable assistance with the necropsy. We are grateful to Professor H.-J. Hansen for valuable discussions.
Claes Rehbinder \& Lars Petersson, National Veter1nary Institute, Uppsala, Sweden.

\section{References}

Barlow RM, Butler EJ. An ataxic condition in red deer (Cervus elaphus) J. comp. Path. 1964, 74, 519-529.

Bjork G, Everz KE, Hansen H-J, Henrıcson B: Congenital cerebellar ataxia in the Gotland pony breed. Zbl. Vet. Med. A. 1973, 20, 341-354.

Calne DB, Eisen A, McGeer E, Spencer P: Alzheimer's disease. Parkinson's disease, and motoneuron disease:: Abiotrophic interaction between aging and environment. Lancet. 1986, 2, 1067-70.

Cordy DR, Knight HD: California goats with a disease resembling enzootıc ataxia or swayback. Vet. Pathol. 1978, 15, 179-185.

Fell BF: The pathology of copper deficiency in an1mals. In: Howell J Mc C, Gawthorne JM (eds.). Copper in anımals and man. Vol II. CRC Press. Inc. Boca Raton, Florida 1987, pp 1-28.

Flynn A, Franzmann AW, Arneson PD, Oldemeyer $J L$ : Indications of copper deficiency in a subpopulation of Alaskan moose. J. Nutrit. 1977, 107, 1182-1189.

Frank $A$. Några spår och mineralamnen. For lite for mycket. Effekter (Some trace - and mineral elements Too little - too much. Effects). In: Hammarberg (ed): Fårhalsovård och fårsjukdomar. SVS - Lantbruksstyrelsen. Borås 1992, pp 51-58.

Gawthorne JM Copper interactions In. Howell J Mc C, Gawthorne JM (eds.): Copper in anımals and man. Vol I. CRC Press, Inc. Boca Raton, Florida 1987 pp. 79-99.

Harper PAW, Duncan DW, Plant JW, Smeal MG. Cerebellar abiotrophy and segmental axonopathy: Two syndromes of progressive ataxia of Merino sheep. Aust. vet J. 1986, 63, 18-21.

Lahunta A. Abiotrophy in domestic anımals: A review. Can. J. vet. Res. 1990, 54, 65-76.

Rogers PAM: Copper and lodine deficiency in cattle. Ir. Grassland. Anım. Prod. An. J. 1991, 25, 117124.

Smith B, Coup MR Hypocuprosis. A clinical investigation of dairy herds in Northland. N.Z. vet. J. 1973, 21, 252.

Suttle NF: Assessment of the mineral and trace element status of feeds. In: Robards GE, Packtram RG (eds.). Proc. 2nd Symp. Int. Network Feed 
Inform. Commonwealth Agricultural Bureaux, Farnham Royal 1983, pp. 211-238.

Suttle NF. Trace element disorders: In: Andrews AH, Blowey RW, Boyd H, Eddy RG. (eds ). Bovine medicine. Diseases and husbandry of cattle. Blackwell Scientific Publications. Oxford 1992, pp. 262-265.

Suttle NF, Field AC: Effect of intake of copper, molybdenum and sulfate on copper metabolism in sheep. IV: Production of congenital and delayed swayback. J. comp. Path. 1969, 79, 453-464.
Wikse SE, Herd D, Field R, Holland P. Diagnosis of copper deficiency in cattle. J. Amer. vet. med. ass. 1992, 200, 1625-1629.

Williams ES, Young $S \cdot$ Neuropathology of chronic wastıng disease of mula deer (Odocoileus hemonius) and elk (Cervus elaphus nelsoni). Vet. Pathol. 1993, 30, 36-45.

Wilson PR, Or, MB, Key EL Enzootic ataxı in red deer. N.Z. vet J. 1979, 27, 252-254.

(Recelved October 4, 1993; accepted December 3, 1993).

Reprınts may be requested from: C. Rehbınder, National Veterınary Laboratory, S-77007 Uppsala, Sweden. 